\title{
27. PALEOMAGNETISM AND ROCK MAGNETISM OF SUBMARINE BASALTS FROM THE GALAPAGOS SPREADING CENTER NEAR $86^{\circ} \mathrm{W}^{1}$
}

\author{
Shaul Levi, School of Oceanography, Oregon State University, Corvallis, Oregon
}

\begin{abstract}
Paleomagnetic and rock magnetic results of basalts drilled during DSDP Leg 70, associated with the Galapagos Spreading Center near $86^{\circ} \mathrm{W}$, show that in this area of high amplitude magnetic anomalies the rocks are characterized by unusually high magnetization intensities $-J_{\text {NRM }}=20 \times 10^{-3}$ gauss-for Sites 506-508, whose ages are $0.5-0.8 \mathrm{~m} . \mathrm{y}$. Magnetic measurements of $J_{\mathrm{NRM}}, \chi$, and $Q$ and paleoinclination data are consistent with a relatively uncomplicated 0.5 to 1-km-thick magnetized layer, responsible for the observed magnetic anomalies at Sites 506-508 and Site 510. The magnetic measurements suggest that Site 510 , which is $2.7 \mathrm{~m} . \mathrm{y}$. old, is outside the zone of high amplitude magnetic anomalies.
\end{abstract}

\section{INTRODUCTION}

The Galapagos Spreading Center (GSC) near $86^{\circ} \mathrm{W}$ is characterized by unusually high amplitude magnetic anomalies (e.g., Herron and Heirtzler, 1967; Raff, 1968). Chemical analyses of basalts dredged and drilled in this region show that they are enriched in iron and titanium relative to "normal" oceanic tholeiites (Anderson et al., 1975; Vogt and de Boer, 1976; Christie and Sinton, 1981). Furthermore, it has been observed that near $86^{\circ} \mathrm{W}$ the high amplitude magnetic anomalies terminate north of the spreading center, becoming "normal" amplitude anomalies over crust older than about $3 \times 10^{6}$ years (Sclater and Klitgord, 1973). Our primary objective during Leg 70 was to study basement basalts from the GSC near $86^{\circ} \mathrm{W}$ as a function of distance from the spreading center in order to examine the evolution of their magnetic properties as the crust ages and moves away from the spreading axis. The basalts obtained by the Deep Sea Drilling Project (DSDP) Leg 70 complement those sampled by the deep submersible Alvin at the axis of the GSC near $86^{\circ} \mathrm{W}$ (Corliss et al., 1979), whose magnetic properties we are presently studying (Levi, 1980).

During Leg 70, basement was sampled at Sites 506, 507,508 , and 510 , whose ages are, respectively, 0.54 , $0.69,0.85$, and 2.73 m.y. (Fig. 1). Basement ages of the younger three sites were determined using a $35 \mathrm{~mm} / \mathrm{y}$. half-spreading rate (Klitgord and Mudie, 1974), and the basement age of Site 510 was obtained using a $32.5 \mathrm{~mm} /$ y. half-spreading rate (Sclater and Klitgord, 1973). During Leg 54 the Glomar Challenger had already drilled Sites 424 and 425 at the GSC near $86^{\circ} \mathrm{W}$, whose spreading ages are 0.7 and $1.8 \mathrm{~m} . y$. ., respectively (Petersen and Roggenthen, 1980).

\section{EXPERIMENTAL PROCEDURE}

The natural remanent magnetization (NRM) was measured on a Digico spinner magnetometer on board the Glomar Challenger; a

\footnotetext{
${ }^{1}$ Honnorez, J., Von Herzen, R. P., et al., Init Repts, DSDP, 70: Washington, D.C. (U.S. Govt. Printing Office).
}

Schonstedt digital spinner magnetometer was used for the shore-based studies. AF (alternating field) demagnetization was carried out using a Schonstedt single-axis demagnetizer both on board ship and at our land-based laboratory. Those specimens that were magnetically "cleaned" were AF demagnetized in progressively higher peak fields of $25,50,75,100,150,200,300,400$, and 500 Oe. If more than $10 \%$ of the remanence remained after the $500 \mathrm{Oe}$ step, $\mathrm{AF}$ demagnetization was continued to 600,800 , and sometimes $1000 \mathrm{Oe}$. The stable directions $\left(I_{\text {stable }}, D_{\text {stable }}\right)$ were chosen individually for each specimen using the plateau or cluster method-that is, from the region of consecutive demagnetization steps, where the directions cluster on a stereographic projection or from the plateau regions of plots of $I$ and $D$ versus demagnetizing fields. Because of the high remanence stability at all the GSC sites, stable directions were readily and unambiguously determined, and it is seen in Table 1 that usually only small changes in magnetic directions occurred during AF demagnetization.

The median demagnetizing field (MDF), the peak alternating field required to demagnetize the NRM to half its initial value, was calculated from demagnetization data.

Thermomagnetic experiments to determine Curie points were carried out on a vertical Curie balance. The heatings were done in vacuum after several flushings with $\mathrm{He}$ gas, and a constant magnetic field (between 1 and $5 \mathrm{kOe}$ ) was applied during each run. Heatings were always carried out to $600^{\circ} \mathrm{C}$, and Curie points were determined by the method described by Grommé and Mankinen (1976).

Susceptibilities were measured on a Bison Co. magnetic susceptibility meter.

\section{RESULTS AND DISCUSSION}

In Table 1 are listed the magnetic properties of individual specimens used in our study. Figure 2 shows histograms of the data for $J_{\text {NRM }}$ (intensity of NRM), $\chi$ (low field susceptibility), and $Q$ (ratio of remanent to induced magnetization: $Q \equiv J_{\mathrm{NRM}} / H_{\chi}$, where $H$ is the intensity of the ambient field at the sampling site). Because of their geographical proximity, comparable ages, and similar magnetic properties the results of Sites 506, 507, and 508 are combined in Figure 2 as well as in Table 2, in which the mean magnetic properties are listed.

\section{Thermomagnetic Analysis}

As submarine basalts extrude on the ocean floor to play their part in contributing to the marine magnetic anomalies, their magnetic phase is a stoichiometric titanomagnetite. Exposure to the seafloor environment causes the progressive low-temperature $\left(\sim 4^{\circ} \mathrm{C}\right)$ oxidation of these titanomagnetites to cation-deficient titano- 


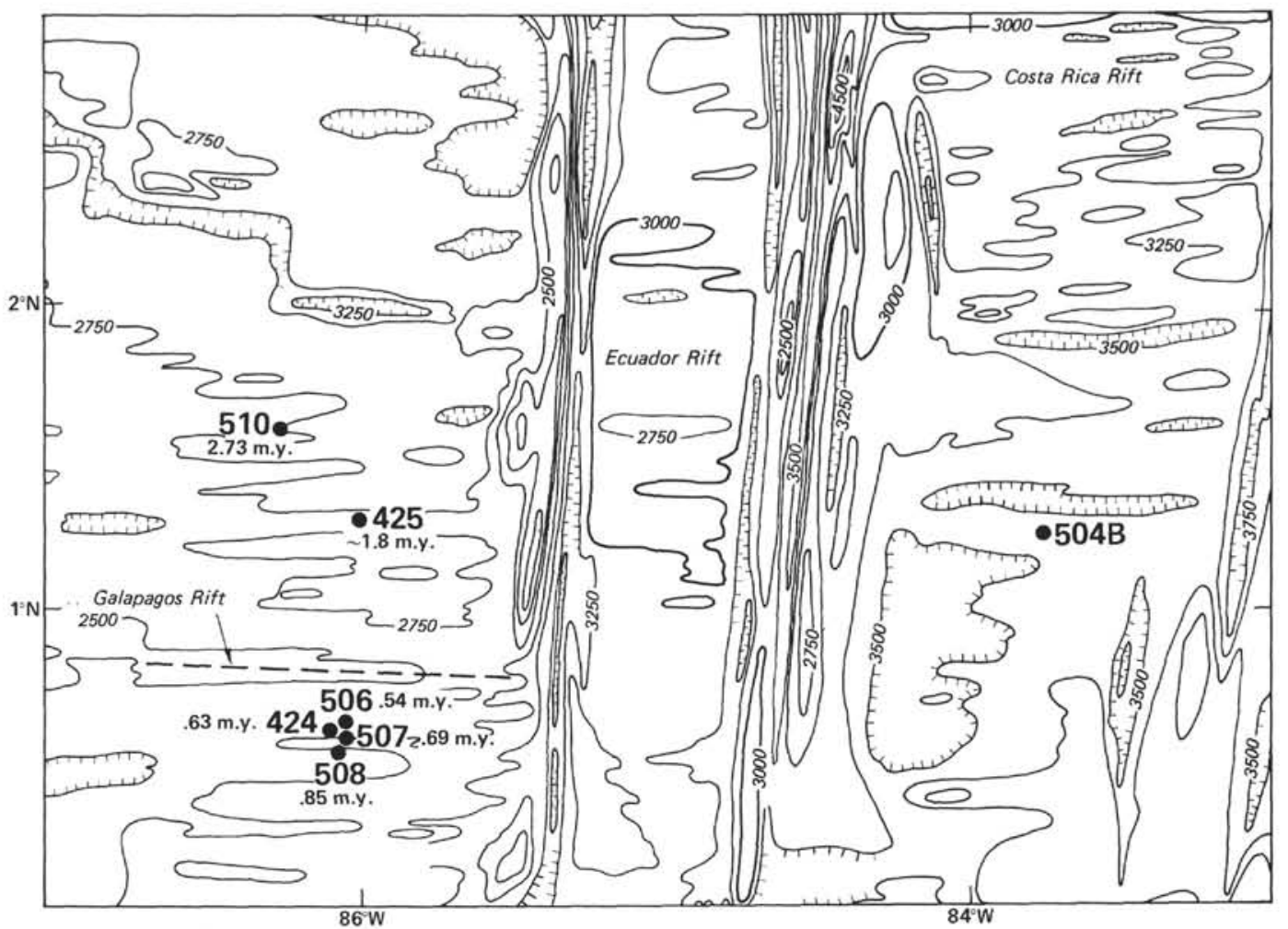

Figure 1. Location map of DSDP sites at the Galapagos Spreading Center near $86^{\circ} \mathrm{W}$, which yielded basement basalts. Leg 54: Sites 424 and 425; Leg 70: Sites 506, 507, 508, and 510.

magnetites, also called titanomaghemites. The progressive oxidation results in (1) a dramatic decrease of the intensity of magnetization during approximately the first million years after initial extrusion, and (2) a progressive increase of the Curie points $\left(T_{c}\right)$ as the titanomagnetite oxidizes to titanomaghemite. This scenario has been revealed during the past dozen or so years through numerous researches carried out by many investigators (e.g., Irving et al., 1970; Ozima and Ozima, 1971; Readman and O'Reilly, 1972; Ozima et al., 1974; Johnson and Atwater, 1977). Furthermore, it has been shown that the titanomagnetites in submarine basalts have a very restricted compositional range between 0.55 and 0.65 mole percent ulvöspinel (Johnson and Hall, 1978). Thus, $T_{c}$ determinations can be very useful in determining the oxidation state of submarine basalts.

$T_{c}$ determinations were obtained from 11 specimens from the GSC sites (individual values in Table 1). The mean values of $T_{c}$ are shown in Table 2. For Sites 506-508, $T_{c}=197^{\circ} \mathrm{C}$; and for Site $510, T_{c}=271^{\circ} \mathrm{C}$. The dispersion in the $T_{c}$ values is thought to be predominantly the result of variations in the magnetic particle sizes, as coarser grains are relatively more resistant to oxidation. Since the ulvospinel content for the GSC rocks has not yet been determined, it is not yet possible to associate a definite oxidation state with the Curie point. However, the data are consistent with the older Site 510 being more oxidized. Figure 3 shows typical thermomagnetic curves from Site 507 and Site 510. The upper curves show nearly reversible behavior whereas the lower curves show highly irreversible thermomagnetic behavior within the same holes.

The Curie points of Sites 506-508 $\left(\bar{T}_{c}=197^{\circ} \mathrm{C}\right)$ are much higher than those obtained by Petersen and Roggenthen for Site $424\left(\bar{T}_{c}=143^{\circ} \mathrm{C}\right)$. In addition, Site 424 has much lower $\overline{\mathrm{MDF}}, \bar{Q}$, and higher $\bar{\chi}$ values than the corresponding Leg 70 GSC sites. All these data are consistent with the interpretation that the basalts of Site 424 contain coarser titanomagnetite grains, which are magnetically less stable and more resistant to oxidation.

\section{Intensity of Magnetization}

The intensity of NRM, $J_{\mathrm{NRM}}$, is a key parameter for modeling the layer thickness responsible for the marine magnetic anomalies. As can be seen from Table 1, there are no significant differences between average values for Sites 506, 507, and 508, and their grouped mean is $20 \times 10^{-3}$ gauss $(\mathrm{G})$. Sclater and Klitgord (1973) used a value of $25 \times 10^{-3} \mathrm{G}$ and a layer thickness of $500 \mathrm{me}-$ ters to model the central anomaly in this area. Klitgord et al. (1975) inverted magnetic anomaly data and, using a 500-meter-thick layer, their calculations yielded 40 $\times 10^{-3} \mathrm{G}$ at the GCS axis and $22 \times 10^{-3} \mathrm{G}$ at 0.5 m.y. Thus, it appears that a layer thickness of 500-1000 meters, assuming that the measured $J_{\mathrm{NRM}}$ are representative values, would be sufficient for explaining the observed magnetic anomalies at the GSC near $86^{\circ} \mathrm{W}$.

$\bar{J}_{\mathrm{NRM}}$ for Sites 506,507 , and 508 is very high relative to other oceanic basalts, especially in view of their equatorial locations; indeed, the individual $J_{\text {NRM }}$ values are 
Table 1. Magnetic properties of specimens from GSC near $86^{\circ} \mathrm{W}$.

\begin{tabular}{|c|c|c|c|c|c|c|c|c|c|c|}
\hline $\begin{array}{c}\text { Sample }{ }^{\mathrm{a}} \\
\text { (interval in } \mathrm{cm} \text { ) }\end{array}$ & $J_{\mathrm{NRM}^{\mathrm{b}}}^{\mathrm{b}}$ & $\chi^{\mathrm{c}}$ & $Q^{\mathrm{d}}$ & $\mathrm{MDF}^{\mathrm{e}}$ & $I_{\mathrm{NRM}}{ }^{\mathrm{f}}$ & $I_{\text {stable }}{ }^{\mathrm{g}}$ & $D_{\text {NRM }^{f}}{ }^{\mathrm{f}}$ & $D_{\text {stable }}{ }^{\mathrm{g}}$ & $T_{c}\left({ }^{\circ} \mathrm{C}\right)^{\mathrm{h}}$ & Comments \\
\hline \multicolumn{11}{|l|}{ Hole 506G } \\
\hline $\begin{array}{l}2-1,29-31, \text { A } \\
2-1,29-31, \text { B } \\
2-1,40-42, \text { A } \\
2-1,40-42, \text { B } \\
2-1,58-60 \\
2-1,77-79 \\
2-1,84-86 \\
2-1,86-88\end{array}$ & $\begin{array}{l}24.0 \\
24.1 \\
18.3 \\
16.5 \\
11.4 \\
31.7 \\
14.3 \\
10.0\end{array}$ & $\begin{array}{l}1.06 \\
1.28 \\
1.57 \\
1.33 \\
3.17 \\
1.16 \\
2.20 \\
2.20\end{array}$ & $\begin{array}{l}69 \\
57 \\
35 \\
38 \\
11 \\
83 \\
20 \\
14\end{array}$ & $\begin{array}{l}179 \\
168 \\
132 \\
173 \\
110 \\
193 \\
108 \\
124\end{array}$ & $\begin{array}{r}-25 \\
-21 \\
-18 \\
-21 \\
-1 \\
-33\end{array}$ & $\begin{array}{r}-27 \\
-24 \\
-16 \\
(3)^{\mathrm{i}} \\
-20 \\
-1 \\
\\
\text { (1) }^{-40}\end{array}$ & $\begin{array}{r}338 \\
337 \\
267 \\
267 \\
\\
\\
349 \\
93\end{array}$ & $\begin{array}{r}335 \\
336 \\
265 \\
264 \\
(2)^{i}{ }^{1} \\
349 \\
\\
\text { (8) } \\
96\end{array}$ & 186 & Unoriented \\
\hline \multicolumn{11}{|l|}{ Hole 506I } \\
\hline $\begin{array}{l}1-1,10-12 \\
1-1,20-22, \mathrm{~A} \\
1-1,20-22, \mathrm{~B}\end{array}$ & $\begin{array}{l}17.6 \\
31.1 \\
33.5\end{array}$ & $\begin{array}{l}0.95 \\
0.92 \\
1.18\end{array}$ & $\begin{array}{r}56 \\
102 \\
86\end{array}$ & $\begin{array}{l}204 \\
173\end{array}$ & $\begin{array}{l}-0 \\
-3\end{array}$ & $\begin{array}{l}-1 \\
-2\end{array}$ & $\begin{array}{l}43 \\
43\end{array}$ & $\begin{array}{l}44 \\
46\end{array}$ & 183 & Unoriented \\
\hline \multicolumn{11}{|l|}{ Hole 507B } \\
\hline $\begin{array}{l}1-1,10-13 \\
1-1,18-22 \\
1-1,25-27 \\
1-1,43-46 \\
1-1,53-55 \\
2-1,13-15\end{array}$ & $\begin{array}{l}28.8 \\
12.0 \\
12.4 \\
13.6 \\
16.3 \\
12.5\end{array}$ & $\begin{array}{l}2.21 \\
2.90 \\
2.04 \\
2.41 \\
1.98 \\
0.70\end{array}$ & $\begin{array}{l}39 \\
13 \\
18 \\
17 \\
25 \\
54\end{array}$ & $\begin{array}{r}74 \\
81 \\
94 \\
188 \\
118 \\
297\end{array}$ & $\begin{array}{r}10 \\
14 \\
14 \\
-27\end{array}$ & $\begin{array}{lr}\text { (10) } & 8 \\
\text { (5) } & 10 \\
& 8 \\
-28\end{array}$ & $\begin{array}{r}208 \\
145 \\
\\
316 \\
73\end{array}$ & 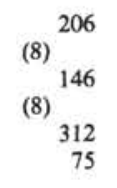 & $\begin{array}{l}163 \\
234\end{array}$ & $\begin{array}{l}\text { Unoriented } \\
\text { Unoriented }\end{array}$ \\
\hline \multicolumn{11}{|l|}{ Hole $507 \mathrm{C}$} \\
\hline $1-1,5-8$ & 39.9 & 1.48 & 82 & 139 & -12 & -12 & 277 & 277 & & \\
\hline \multicolumn{11}{|l|}{ Hole 508B } \\
\hline $\begin{array}{l}3-1,3-5 \\
4-1,3-5, \text { A } \\
4-1,3-5, \text { B }\end{array}$ & $\begin{array}{l}\overline{11.2} \\
13.6\end{array}$ & $\begin{array}{l}0.68 \\
0.79 \\
0.88\end{array}$ & $\begin{array}{l}-\overline{43} \\
47\end{array}$ & $\overline{216}$ & $\overline{-4}$ & $\overline{-2}$ & $\overline{170}$ & (2) & 237 & $\begin{array}{l}\text { Unoriented } \\
\text { Unoriented }\end{array}$ \\
\hline \multicolumn{11}{|l|}{ Hole 510A } \\
\hline $\begin{array}{l}8-2,100-102 \\
8-2,104-106 \\
8-2,110-113 \\
8-c c, 8-10 \\
9-1,14-16\end{array}$ & $\begin{array}{l}6.2 \\
5.5 \\
5.5 \\
6.5 \\
4.1\end{array}$ & $\begin{array}{l}1.12 \\
0.91 \\
0.72 \\
0.85 \\
0.90\end{array}$ & $\begin{array}{l}17 \\
18 \\
23 \\
23 \\
14\end{array}$ & $\begin{array}{l}162 \\
257\end{array}$ & $\begin{array}{r}-7 \\
-2 \\
-19 \\
-2 \\
-3\end{array}$ & $\begin{array}{r}-5 \\
-19\end{array}$ & $\begin{array}{l}292 \\
294 \\
134 \\
294 \\
284\end{array}$ & $\begin{array}{l}294 \\
134\end{array}$ & 271 & \\
\hline $\begin{array}{l}9-1,14-16 \\
9-1,57-60\end{array}$ & $\begin{array}{r}4.1 \\
16.2\end{array}$ & $\begin{array}{l}0.90 \\
0.97\end{array}$ & $\begin{array}{l}14 \\
51\end{array}$ & $\begin{array}{l}185 \\
157\end{array}$ & -3 & (2) & 284 & $(3)^{285}$ & & Unoriented \\
\hline $9-1,76-79$ & 3.9 & 0.82 & 14 & & -13 & & 256 & & 261 & \\
\hline $9-1,82-84$ & 5.6 & 1.64 & 10 & 145 & -19 & -20 & 182 & 179 & & \\
\hline $9-1,122-125$ & 4.5 & 0.78 & 17 & 150 & -10 & -16 & 93 & 98 & & \\
\hline $9-1,129-131$ & 2.8 & 0.81 & 10 & & -4 & & 99 & & & \\
\hline $\begin{array}{l}9-2,6-8 \\
9-2,10-12\end{array}$ & $\begin{array}{l}9.7 \\
2.8\end{array}$ & $\begin{array}{l}1.07 \\
0.30\end{array}$ & $\begin{array}{l}27 \\
28\end{array}$ & 322 & $\begin{array}{l}-17 \\
-18\end{array}$ & -18 & $\begin{array}{l}63 \\
62\end{array}$ & 60 & & \\
\hline $9-2,52-55$ & 5.5 & 1.05 & 16 & & -17 & & 258 & & & \\
\hline $9-2,59-61$ & 4.7 & 1.03 & 14 & 138 & -14 & -21 & 265 & 264 & & \\
\hline $9-2,65-67$ & 2.4 & 0.17 & 42 & 659 & -6 & -16 & 128 & 138 & & \\
\hline $9-2,94-96$ & 6.6 & 0.78 & 26 & & -11 & & 87 & & & \\
\hline $9-2,96-98$ & 5.6 & 1.15 & 15 & 141 & -6 & -12 & 258 & 254 & & \\
\hline $9-2,120-123$ & 5.1 & 1.07 & 14 & 145 & -20 & -22 & 226 & 223 & & \\
\hline $9-3,15-17$ & 1.7 & 0.61 & 8 & 181 & -16 & -17 & 333 & 338 & & \\
\hline $9-3,18-20$ & 1.8 & 0.50 & 11 & & -11 & & 30 & & & \\
\hline $9-3,34-36$ & 5.1 & 0.89 & 17 & 138 & -8 & -11 & 194 & 192 & & \\
\hline $9-3,39-42$ & 4.5 & 0.69 & 20 & & -10 & & 192 & & & \\
\hline $9-3,57-59$ & 3.3 & 0.25 & 40 & 373 & -20 & -20 & 296 & 295 & 295 & \\
\hline $10-1,14-16$ & 22.5 & 1.00 & 68 & 170 & -28 & -28 & 97 & 100 & & \\
\hline $10-1,26-28$ & 4.9 & 1.37 & 11 & 125 & & & & & & Unoriented \\
\hline $10-1,34-36$ & 2.8 & 1.01 & 9 & 122 & 5 & 11 & 88 & 94 & 256 & \\
\hline $10-1,52-54$ & 4.0 & 1.27 & 10 & 99 & 5 & 8 & 275 & 277 & & \\
\hline $10-1,73-75$ & 4.2 & 1.35 & 9 & 111 & -3 & -12 & 273 & 266 & & \\
\hline $11-1,34-36$ & 3.5 & 0.35 & 30 & 319 & -10 & -10 & 184 & 183 & 274 & \\
\hline
\end{tabular}

a Sample Identification: For example, 508B-4-1, 3-5 cm, B is Site 508, Hole B, Core 4 ( $\leq 9.5 \mathrm{~m}$ ), Section 1 ( $\leq 7$ per core), sampled interval $3-5 \mathrm{~cm}(\leq 150 \mathrm{~cm})$; A or B after the sampled interval indicates that the sample cylinder was divided into two parts, one for magnetic measurements and the other for density and sonic velocity measurements. (This procedure was adopted

as a result of poor penetration and recovery at the GSC sites.)

$J_{\mathrm{NRM}}$ : Intensity of natural remanent magnetism, NRM $\left(\times 10^{-3}\right.$ gauss).

c $\chi$ : Low field susceptibility $\left(\times 10^{-3}\right.$ gauss/oersted).

d $Q \equiv J_{\mathrm{NRM}} / H_{\chi}$ (for this study $H=0.33$ oersted).

e MDF: Median demagnetizing peak alternating field of NRM (oersted).

${ }^{\mathrm{f}} \mathrm{I}_{\mathrm{NRM}}, D_{\text {NRM }}$ : NRM inclination, NRM relative declination (degrees).

I IStable, $D$ Stable: Stable inclination, stable relative declination (degrees).

h $T_{c}$. First Curie temperature on initial heating, determined from thermomagnetic analyses.

${ }^{\mathrm{i}}$ For unoriented samples number in () indicates difference between NRM and STABLE values of $I$ and $D$. 

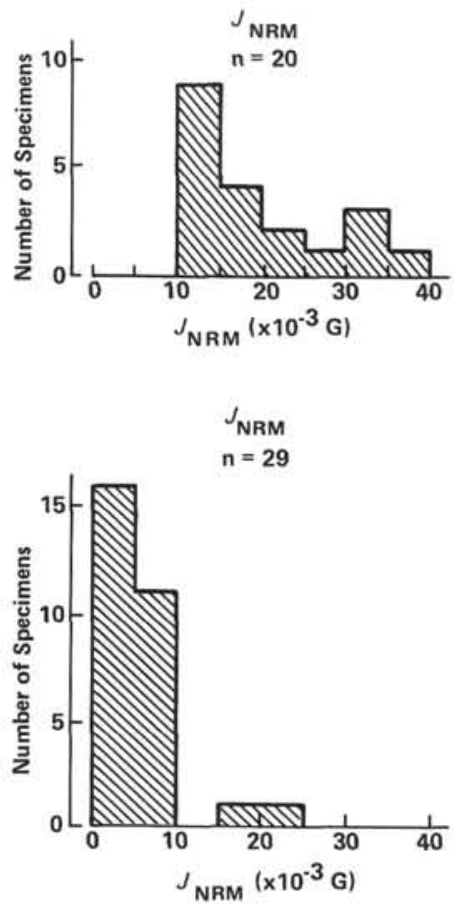

Sites 506, 507, 508
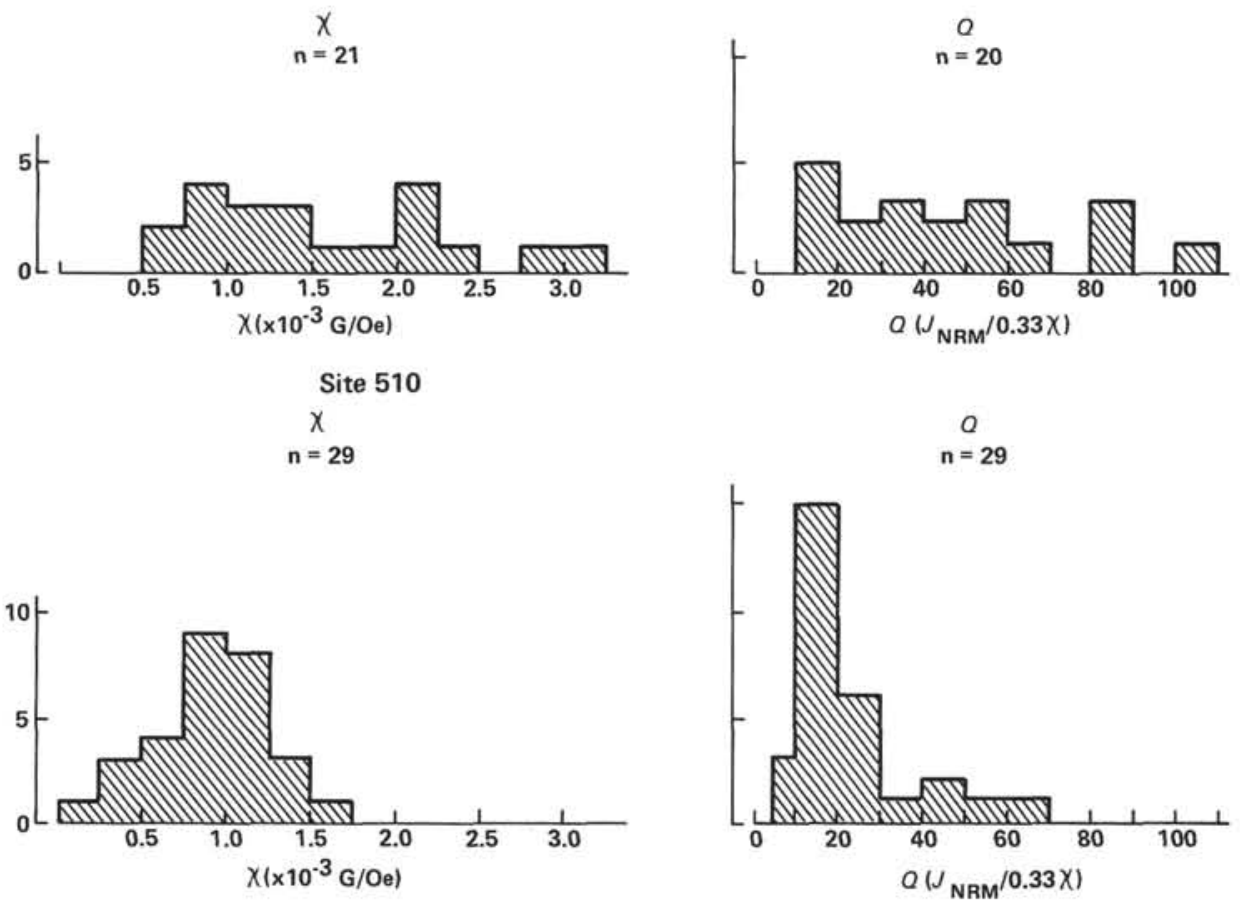

Figure 2. Histograms of $J_{\text {NRM }}, \chi$, and $Q$ for Sites 506, 507, 508 and for Site 510.

Table 2. Average magnetic properties of Leg 70 sites at GSC near $86^{\circ} \mathrm{W}$.

\begin{tabular}{|c|c|c|c|c|c|c|}
\hline Site & $\begin{array}{l}\text { Basement } \\
\text { Age (m.y.) }\end{array}$ & $\bar{J}_{\mathrm{NRM}^{\mathrm{a}}}{ }^{\mathrm{a}}$ & $\bar{\chi}^{\mathrm{a}}$ & $\bar{Q}^{\mathrm{a}}$ & $\overline{\mathrm{MDF}}^{\mathrm{a}}$ & $\bar{T}_{\mathrm{c}}^{\mathrm{a}}$ \\
\hline 506 & 0.54 & & & & & \\
\hline 507 & 0.69 & $19.6 \pm 9.0^{b}(20)^{c}$ & $1.58 \pm 0.73(21)$ & $45 \pm 28(20)$ & $157 \pm 57$ (17) & $197 \pm 31(6)$ \\
\hline $\begin{array}{l}508 \\
510\end{array}$ & 0.85 & & & & $173+73(18)$ & $271+15(5)$ \\
\hline 510 & 2.73 & $5.6 \pm 4.2(29)$ & $0.88 \pm 0.34$ (29) & $21 \pm 14(29)$ & $173 \pm 73(18)$ & $271 \pm 15(5)$ \\
\hline
\end{tabular}

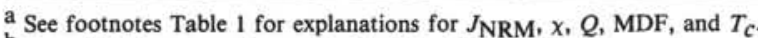

b Uncertainties represent one standard deviation (s).

c Number in () specifies the number of specimens used in determining mean and $s$.

comparable to values of zero age crust in the FAMOUS area of the Mid-Atlantic Ridge (Johnson and Atwater, 1977). In contrast, $\bar{J}_{\mathrm{NRM}}$ of Sites $506-508$ is only about one-third the $\bar{J}_{\text {NRM }}$ value at the axis of the GSC, just 19-26 km north of our sites (Anderson et al., 1975; Levi, 1980). The large decrease in $\bar{J}_{\mathrm{NRM}}$ with age or distance from the spreading axis is probably associated with progressive low temperature oxidation of the primary titanomagnetites, which previous studies in the Atlantic Ocean have shown to be important in affecting the diminution with age of $\bar{J}_{\text {NRM }}$ (Irving, 1970; Johnson and Atwater, 1977).

$\bar{J}_{\mathrm{NRM}}$ at Site 510 is less than one-third that at Sites 506-508, and this is thought to be too large a decrease to be explained entirely by progressive low temperature oxidation, because the initial decrease of $J_{\mathrm{NRM}}$ with age had already taken place. Furthermore, microscopic observations suggest a lesser abundance of titanomagnetite grains for Site 510 than for the younger Leg 70 sites. Thus, it is possible that Site 510 is just outside the zone of high amplitude magnetic anomalies and is not composed of the so-called high FETI basalts (see Emmer- mann, et al., Table 5, this volume). At Site $510 \bar{J}_{\mathrm{NRM}}$ $=5.6 \times 10^{-3} \mathrm{G}$. This value is very similar to the value $6.25 \times 10^{-3} \mathrm{G}$ used by Sclater and Klitgord (1973) to model the magnetic anomalies in this area with a 500 meter-thick basement layer.

\section{Susceptibilities}

The average susceptibility at Site 510 is about half that of Sites 506-508, consistent with a lesser Fe-content in the former. However, it is well known that susceptibility is not merely a function of concentration. This is illustrated in Figure 4, where we plotted MDF versus $\chi$ of individual specimens. Clearly, higher $\chi$ is associated with lower MDF and lower $\chi$ with higher MDF. MDF reflects the average stability or grain size of a specimen, such that higher $\chi$ is associated with less stable, usually larger grain sizes and vice versa. Although the data from Sites $\mathbf{5 0 6 - 5 0 8}$ and Site $\mathbf{5 1 0}$ follow the same trend, it is seen that the results of Sites 506-508 are displaced to higher values of $\chi$. The solid symbols in Figure 4 represent the mean values with associated standard errors for Sites 506-508 and Site 510, and it is apparent that $\bar{\chi}$ of 

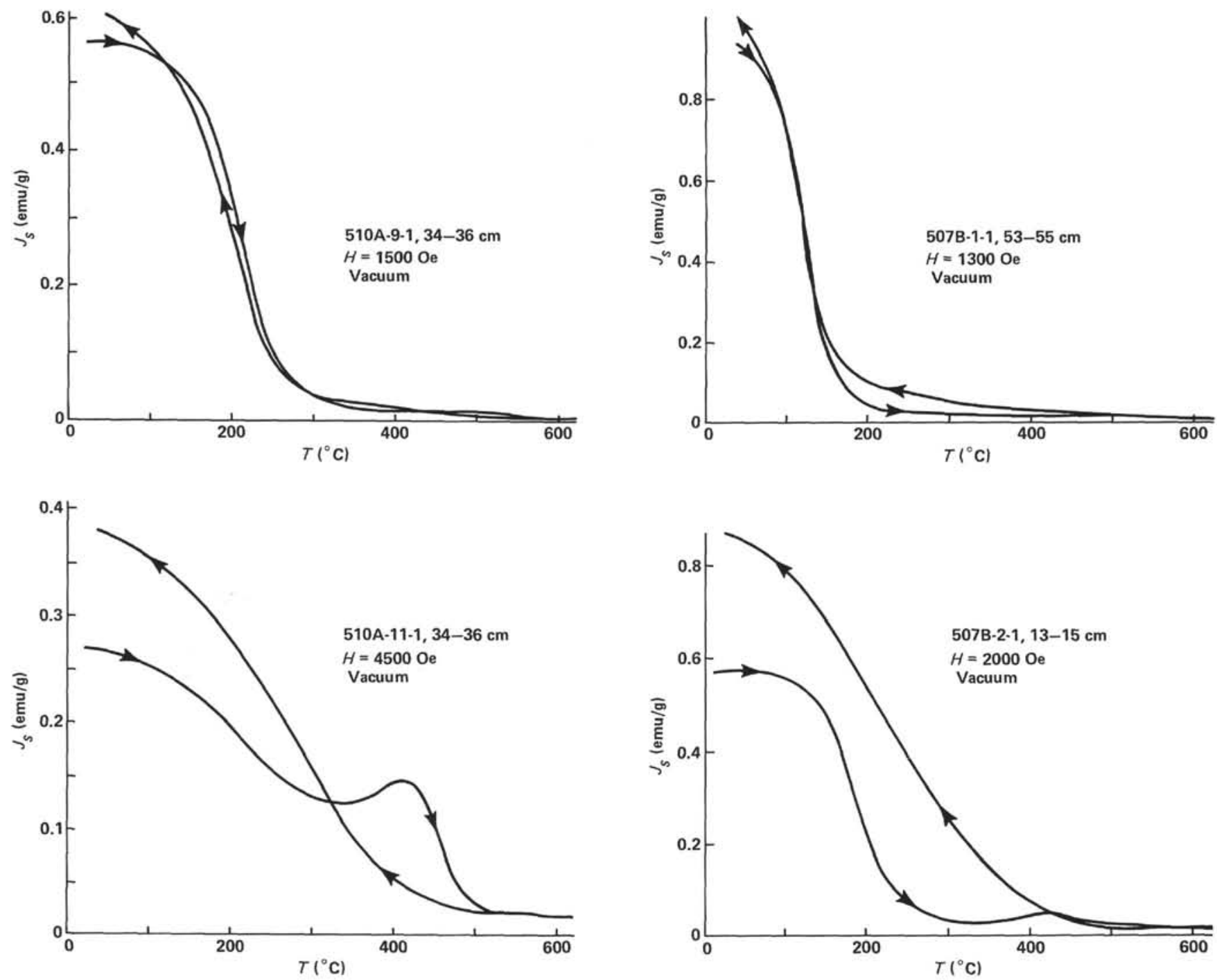

Figure 3. Thermomagnetic experiments of strong field magnetization vs, temperature for representative specimens. (All runs were made in vacuum. Heating and cooling curves are indicated by arrows.)

Sites 506-508 is significantly higher than that of Site 510 , although the values of $\overline{\mathrm{MDF}}$ are not significantly different.

\section{The $Q$ Parameter}

The values of $Q$ are much greater than unity for all specimens of all the GSC sites, implying that induced magnetization is much less significant than the remanence. This, of course, is consistent with the presence of distinct magnetic anomalies in this area. Interestingly, $Q$ at Site 510 is about half that of Sites $506-508$. This is a result of the fact that $\bar{J}_{\mathrm{NRM}}$ at Site 510 is about onefourth and $\bar{\chi}$ about one-half of these values for Sites 506-508.

\section{Median Demagnetizing Fields}

In contrast to the systematic differences observed in $\bar{J}_{\text {NRM }}, \bar{\chi}$, and $\bar{Q}$ between Site 510 and Sites 506-508, there is essentially no difference in their $\overline{\mathrm{MDF}}$ values (Table 2). Of all the parameters of Tables 1 and 2 the
MDF is the best indicator of the intrinsic magnetic stability of a specimen's remanence-carrying particles, and, all else being equal, it might be used as a gross indicator of relative particle sizes. Thus, if the same magnetic mineralogy is assumed for all sampled GSC sites, and if it is further assumed that submarine low temperature oxidation has a relatively small effect on $\overline{\mathrm{MDF}}$ (i.e., not much greater than the differences observed in Table 2), then the similarity in $\overline{\mathrm{MDF}}$ values might suggest that comparable particle-size distributions are responsible for the remanence at Site 510 and Sites 506-508. Furthermore, if the mineralogy and particle size distributions are similar, then our data (Table 2) might suggest that submarine progressive low temperature oxidation is more effective at decreasing $J_{\mathrm{NRM}}$ than $\chi$.

Petersen and Roggenthen (1980) studied the rock and paleomagnetism of Sites 424 and 425 , which were drilled during Leg 54. Site 424 was very close to Sites 506-508 (about 0.7 m.y.), and Site 425 was north of the GSC axis on approximately $1.8 \mathrm{~m} . \mathrm{y}$. old crust. Interestingly, $J_{\mathrm{NRM}}$ 


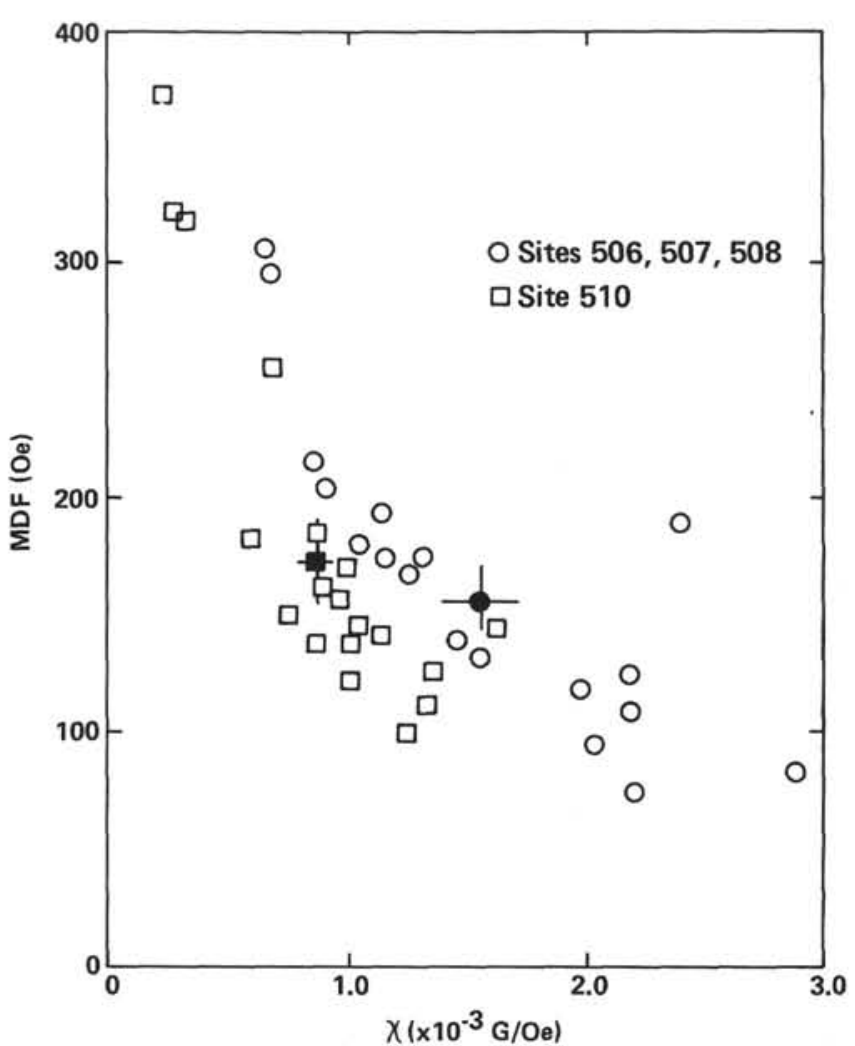

Figure 4. MDF vs. $\chi$ plot for the Leg 70 GSC sites. (The solid symbols represent the mean values for the corresponding ensemble of open symbols, and the associated bars represent the appropriate standard error.)

of Sites 424 and 425 was about half the value at Sites 506-508, and $Q$ was also considerably lower than at Sites 506-508, with only 13 of 36 values exceeding $Q=$ 10 and $Q_{\text {MAX }}=41$. In addition, $\chi$ at Sites 424 and 425 was much higher and the MDF much lower than at Sites 506-508. The differences between the Leg 54 and Leg 70 paleomagnetic results of their GSC sites are consistent with the presence of coarser and magnetically less stable titanomagnetite particles in the basalts of Sites 424 and 425 than for Sites 506-508. This contrast between similar-aged Site 424 and Sites $506-508$ is further evidence for the heterogeneity of the magnetic properties of submarine basalts occurring on scales of centimeters to kilometers. Such heterogeneity has been previously noted in studies of DSDP basalts (e.g., Levi, 1980b).

\section{Paleomagnetic Directions}

Because DSDP cores are azimuthally unoriented, only the inclinations are available for polarity determinations. However, the equatorial latitudes of the GSC sites preclude the possibility of determining their polarities solely on the basis of inclination data.

Because of the poor penetration and recovery of basement basalts at the GSC sites, there were only relatively few pieces of cored rock available for which it was possible to neglect potential misorientation resulting from end-over-end rotation in the core barrel. Only sufficiently long pieces of cored basalt were selected for inclination determinations. All oriented pieces were longer than $6 \mathrm{~cm}$, but none was longer than $15 \mathrm{~cm}$; most were in the $7-10 \mathrm{~cm}$ range.

The NRM directions are very stable and include at most minor contributions of secondary remanence. This is demonstrated by the small angular change of directions during AF demagnetization. Thus, the NRM directions are excellent indicators of the final stable directions. (There is no evidence in these specimens that the remanence was affected by drilling.)

It is usually assumed in paleomagnetism that the time-averaged geomagnetic field during the last few million years can be approximated by a geocentric axial dipole (GAD). Such a field would produce essentially zero inclination at the Leg 70 sites. However, the instantaneous field may vary considerably from its time-averaged configuration. For example, the present inclination in the region of Leg 70 drilling is $+20^{\circ}$. In addition, the angular dispersion of paleomagnetic directions is maximum at the equator and its value there resulting from geomagnetic secular variation approaches $20^{\circ}$ (McElhinny and Merrill, 1975). Hence normal geomagnetic secular variation can give rise to instantaneous field directions which are markedly different than the time-averaged field.

The NRM and stable directions of basement rocks at all our GSC sites are characterized by generally shallow inclinations (Table 1), consistent with their equatorial position. Site 506 exhibits negative inclinations whose values are shallower than $-27^{\circ}$, with the exception of a single specimen whose stable inclination is $-40^{\circ}$. Sites 507 and 508 have shallow inclinations, which are both negative and positive. For one specimen $I_{\text {stable }}=-28^{\circ}$, and for the remaining samples $\left|I_{\text {stable }}\right|<12^{\circ}$. Site 510 recorded predominantly negative inclinations averaging between $-10^{\circ}$ to $-20^{\circ}$ for Cores 8 and 9 , with relatively small dispersion, and no value exceeding $-22^{\circ}$. Cores 10 and 11 of Site 510 have both negative and positive shallow inclinations with a maximum value of $-28^{\circ}$. Though few, the inclination data are entirely consistent with expected angular dispersion of normal geomagnetic secular variation. There is no paleomagnetic evidence for rotation of crustal blocks about a horizontal axis. Since the NRM directions are essentially identical with the stable directions and these are consistent with those expected locally as a result of GAD, it seems that Leg 70 actually drilled into the very material which gives rise to the marine magnetic anomalies at the GSC near $86^{\circ} \mathrm{W}$.

\section{CONCLUSIONS}

1. Basalts drilled during DSDP Leg 70 at the GSC near $86^{\circ} \mathrm{W}$ show that in this area of high amplitude magnetic anomalies the rocks are characterized by unusually high magnetization intensities, $\bar{J}_{\mathrm{NRM}}=20 \times$ $10^{-3}$ gauss, for Sites 506-508 whose ages are 0.5-0.8 m.y.

2. Both rock magnetic measurements and paleoinclination data are consistent with a relatively uncomplicated 0.5 to $1-\mathrm{km}$-thick magnetized layer, responsible for the observed magnetic anomalies at Sites 506-508 and Site 510. 
3. Rock magnetic measurements suggest that Site $510,2.7$ m.y., is outside the zone of high amplitude magnetic anomalies.

\section{ACKNOWLEDGMENTS}

The thermomagnetic analyses were done on the USGS Curie balance in Menlo Park, California, and I wish to thank C. S. Grommé, J. Hillhouse, and E. A. Mankinen for their help, hospitality, and for letting me use their laboratory. I thank D. Schultz for doing the shorebased magnetic measurements. This research was funded by the National Science Foundation Division of Ocean Science (OCE 7919230). R. A. Duncan, H. P. Johnson, and R. Karlin provided helpful reviews.

\section{REFERENCES}

Anderson, R. N., Clague, D. A., Klitgord K. D., Marshall, M., and Nishimori, R. K., 1975. Magnetic and petrologic variations along the Galapagos Spreading Center and their relation to the Galapagos melting anomaly. Bull. Geol. Soc. Am., 86:683-694.

Christie, D. M., and Sinton, J. M., 1981. Evolution of abyssal lavas along propagating segments of the Galapagos Spreading Center. Earth Planet Sci. Lett., 56:321-335.

Corliss, J. B. and ten other authors, 1979. Submarine thermal springs on the Galápagos rift. Science, 203:1073-1083.

Grommé, C. S., and Mankinen, E. A., 1976. Natural remanent magnetization, magnetic properties, and oxidation of titanomagnetite in basaltic rocks from DSDP, Leg 34. In Yeats, R. S., Hart, S. R., et al., Init. Repts. DSDP, 34: Washington (U.S. Govt. Printing Office), 485-494.

Herron, E. M., and Heirtzler, J. R., 1967. Sea-floor spreading near the Galapagos. Science, 158:775-779.

Irving, E., 1970. The Mid-Atlantic Ridge at $45^{\circ} \mathrm{N}$. XIV. Oxidation and magnetic properties of basalt; review and discussion. Can. J. Earth Sci., 7:1528-1538.

Irving, E., Robertson, W. A., and Aumento, F., 1970. The MidAtlantic Ridge near $45^{\circ} \mathrm{N}$. VI. Remanent intensity, susceptibility and iron content of dredged samples. Can. J. Earth Sci., 7: 226-238.

Johnson, H. P., and Atwater, T., 1977. Magnetic study of basalts from the Mid-Atlantic Ridge, lat. $37^{\circ}$ N. Bull. Geol. Soc. Am., 88: 637-647.
Johnson, H. P., and Hall, J. M., 1978. A detailed rock magnetic and opaque mineralogy study of the basalts from the Nazca Plate. Geophys. J. R. Astron. Soc., 52:45-64.

Klitgord, K. D., Huestis, S. P., Mudie, J. D., and Parker, R. L., 1975. An analysis of near-bottom magnetic anomalies: Sea-floor spreading and the magnetized layer. Geophys. J. R. Astron. Soc., 43: p. 387-424.

Klitgord, K. D., and Mudie, J. D., 1974. The Galapagos Spreading Centre. A near bottom geophysical survey. Geophys. J. R. Astron. Soc., 38:563-586.

Levi, S., 1980a. Magnetic properties of the oceanic crust at the Galapagos spreading center near $86^{\circ} \mathrm{W}$. EOS, Transact. AGU, 61:943. (Abstract)

Levi, S., 1980b. Paleomagnetism and some magnetic properties of basalts from the Bermuda Triangle. In Donnelly, J., Bryan, W., Robinson, P., Flower, M., Salisbury, M., et al., Init. Repts. DSDP, 56, 57, Pt. 2: Washington (U.S. Govt. Printing Office), 1363-1378.

McElhinny, M. W., and Merrill, R. T., 1975. Geomagnetic secular variation over the past 5 MY. Rev. Geophys. Space Phys., 13: 687-708.

Ozima, M., Ozima, M., and Kinoshita, H., 1974. Magnetic properties of submarine basalts and the implications on the structure of the oceanic crust. J. Geomag. Geoelectr., 26:335-354.

Ozima, M., and Ozima, M., 1971. Characteristic thermomagnetic curves in submarine basalts. J. Geophys. Res., 76:2051-2056.

Petersen, N., and Roggenthen, W. M., 1980. Rock and paleomagnetism of Leg 54 basalts-East Pacific Rise and Galapagos areas. In Rosendahl, B. R., Hekinian, R., et al., Init. Repts. DSDP, 54: Washington (U.S. Govt. Printing Office), 865-877.

Raff, A. D., 1968, Sea-floor spreading-Another rift. J. Geophys. Res., 73:3699-3705.

Readman, P. W., and O'Reilly, W., 1972. Magnetic properties of oxidized (cation-deficient) titanomagnetites $(\mathrm{Fe}, \mathrm{Ti}, \square)_{3} \mathrm{O}_{4}, J$. Geomag. Geoelectr., 24:69-90.

Sclater, J. G., and Klitgord, K. D., 1973. A detailed heat flow, topographic and magnetic survey across the Galapagos spreading center at $86^{\circ}$ W. J. Geophys. Res., 78:6951-6975.

Vogt, P. R., and de Boer, J., 1976. Morphology, magnetic anomalies, and basalt magnetization and the ends of the Galapagos highamplitude zone. Earth Planet Sci. Lett., 33:185-207. 